\title{
Effect of Al Addition on Superelastic Properties of Aged Ti-Nb-Zr-Al Quaternary Alloys
}

\author{
Hiroyuki Tada ${ }^{1, *}$, Tokujiro Yamamoto ${ }^{2}$, Xinmin $\mathrm{Wang}^{3}$ and Hidemi Kato ${ }^{3}$ \\ ${ }^{1}$ Graduate School of Engineering, Tohoku University, Sendai 980-8579, Japan \\ ${ }^{2}$ Department of Mechanical Systems Engineering, Utsunomiya University, Utsunomiya 321-8585, Japan \\ ${ }^{3}$ Institute of Materials Research, Tohoku University, Sendai 980-8577, Japan
}

The effect of $\mathrm{Al}$ content on superelastic properties of $\mathrm{Ti}_{75-x} \mathrm{Nb}_{15} \mathrm{Zr}_{10} \mathrm{Al}_{x}(x=0-6$ at $\%$ ) quaternary $\beta$ Ti alloys were investigated. And the effects of baking for coating or plating on superelastic properties were also studied. The alloys containing 3 and 4 at $\%$ of $\mathrm{Al}$ clearly exhibited superelastic behavior after aging at 453 and $553 \mathrm{~K}$, which are appropriate temperatures for industrial coating and plating, respectively. $\mathrm{Ti}_{72} \mathrm{Nb}_{15} \mathrm{Zr}_{10} \mathrm{Al}_{3}$ alloy exhibited the largest recovery strain of $2.5 \%$ due to superelastic behavior even after industrial coating and plating. In this quaternary alloy system, strange non-monotonical change of superelastic behavior as a function of $\mathrm{Al}$ content was also found. [doi:10.2320/matertrans.M2012184]

(Received May 17, 2012; Accepted August 29, 2012; Published October 11, 2012)

Keywords: aging, superelasticity, titanium-niobium based alloy, coating, plating, aluminum

\section{Introduction}

Superelastic TiNi alloys have been widely used as high performance materials, such as orthodontic wires, antennas of mobile phones and eyeglass frames. However, $\beta$-Ti alloys attract more attention than TiNi alloys, because they possess biocompatibility in addition to superelastic property, shape memory effect and low Young's modulus. ${ }^{1-10)}$ In order to produce good superelastic $\beta$-Ti alloys, the change of mechanical properties as a function of aging temperature and period have been studied intensively.,11-17) In recent years, the effect of allergenic and toxic elements on the biocompatibility of superelastic $\beta$-Ti alloys has been also studied. ${ }^{13,18-24)}$ Through those studies, Hosoda et al. reported good superelastic properties of $\mathrm{Ti}-\mathrm{Nb}$-based alloys. ${ }^{12,25)}$ And, Niinomi et al. reported that $\mathrm{Ti}-\mathrm{Nb}-\mathrm{Ta}-\mathrm{Zr}$ alloys exhibit good process-ability and low Young's modulus as a biomaterial. ${ }^{1,26-28)}$

However, many $\beta$-Ti alloys reported so far were aged at much higher temperature than practical temperature for industrial coating and plating, because most studies have focused on how to obtain good superelastic or shape memory behavior. From viewpoint of apparel demand, eyeglasses should be painted or plated at various temperatures for decoration.

Therefore, in this study, the effect of $\mathrm{Al}$ content and low temperature aging was investigated to develop Ni-free $\beta$-Ti alloys showing superelastic behavior, which is not degraded even after practical coating and plating process.

\section{Experimental Procedures}

The nominal compositions of alloys investigated in this study are tabulated in Table 1. Al was substituted for Ti in $\mathrm{Ti}_{75} \mathrm{Nb}_{15} \mathrm{Zr}_{10}$, thus the alloy composition is denoted as

*Corresponding author, E-mail: h.tada@charmant.co.jp. Graduate Student, Tohoku University. Present address: Charmant Inc., Sabae 916-0088, Japan
Table 1 Nominal alloy compositions (at\%) investigated in this study.

\begin{tabular}{lcccc}
\hline & $\mathrm{Ti}$ & $\mathrm{Nb}$ & $\mathrm{Zr}$ & $\mathrm{Al}$ \\
\hline $0 \mathrm{Al}$ & 75 & 15 & 10 & 0 \\
$1 \mathrm{Al}$ & 74 & 15 & 10 & 1 \\
$2 \mathrm{Al}$ & 73 & 15 & 10 & 2 \\
$3 \mathrm{Al}$ & 72 & 15 & 10 & 3 \\
$4 \mathrm{Al}$ & 71 & 15 & 10 & 4 \\
$5 \mathrm{Al}$ & 70 & 15 & 10 & 5 \\
$6 \mathrm{Al}$ & 69 & 15 & 10 & 6 \\
\hline
\end{tabular}

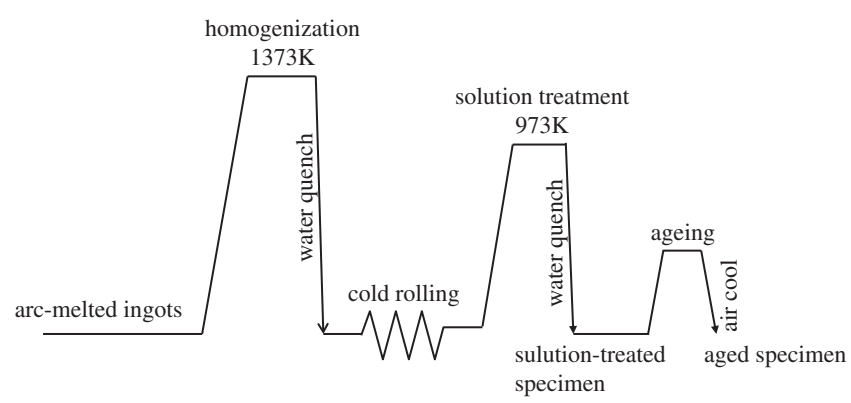

Fig. 1 Heat treatment performed to the arc-melted ingots.

$\mathrm{Ti}_{75-x} \mathrm{Nb}_{15} \mathrm{Zr}_{10} \mathrm{Al}_{x} \quad(x=0-6)$. Hereafter, these alloys are referred as $0 \mathrm{Al}-6 \mathrm{Al}$. The ingots were prepared by arcmelting in an Ar atmosphere. Each ingot was melted 8 times.

Figure 1 schematically shows the history of heat treatment performed to the arc-melted ingots. Firstly, the arc-melted ingots were sealed in a vacuumed quartz tube for homogenization at $1373 \mathrm{~K}$ for $3.6 \mathrm{ks}$, then followed by quenching in water. Secondly, the ingots were cold-rolled up to $80 \%$ reduction until the thickness of the rolled plates was reduced to $1 \mathrm{~mm}$. The specimens for tensile tests were punched out from the cold-rolled plates. More than six sets of specimens were obtained for each alloy composition. Then, the punched-out specimens were solution-treated at $973 \mathrm{~K}$ for $0.6 \mathrm{ks}$ in vacuumed quartz tubes, followed by quenching in 


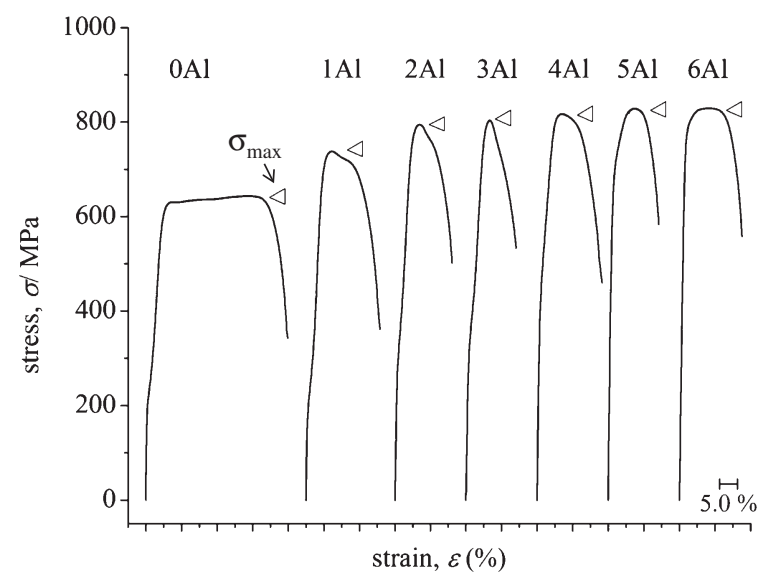

Fig. 2 Stress-strain curves of the $\mathrm{Ti}_{75-x} \mathrm{Nb}_{15} \mathrm{Zr}_{10} \mathrm{Al}_{x}$ specimens solutiontreated at $973 \mathrm{~K}$ for $600 \mathrm{~s}$. Specimens were subjected to tensile tests until failure.

water. Finally, some of the specimens were aged for $3.6 \mathrm{ks}$ at 453 and $553 \mathrm{~K}$. After those heat treatments, the oxidized surface of the specimens was removed by chemical etching or mechanical polishing at room temperature. The solution for etching was $\mathrm{H}_{2} \mathrm{O}, \mathrm{HNO}_{3}$ and $\mathrm{HF}(5: 4: 1)$.

Those specimens were characterized by X-ray diffraction (XRD) using $\mathrm{Cu} K \alpha$ radiation to identify the composing phases. Simple tensile tests were first performed for some solution-treated specimens without aging until failure to measure ultimate tensile strength, $\sigma_{\max }$. The aged specimens were subjected to loading-unloading tensile tests using a strain gauge extensometer at room temperature, where a strain rate was at $5 \times 10^{-4} \mathrm{~s}^{-1}$, to observe superelastic or shape memory behavior. The cross section of the gage was $1 \mathrm{~mm} \times 2 \mathrm{~mm}$, and the gage length was $10 \mathrm{~mm}$. The microstructure was studied using transmission electron microscope (TEM) at an accelerating voltage of $200 \mathrm{kV}$ for solution treated specimen and aged specimen. Specimens for TEM observations were prepared by twn-jet polishing using an electrolyte solution of $6 \mathrm{vol} \%$ perchloric acid and $94 \mathrm{vol} \%$ methanol.

\section{Results and Discussions}

\subsection{The solution-treated specimens}

Figure 2 shows the stress-strain curves of the $\mathrm{Ti}_{75-x} \mathrm{Nb}_{15} \mathrm{Zr}_{10} \mathrm{Al}_{x}$ specimens solution-treated at $973 \mathrm{~K}$ for $0.6 \mathrm{ks}$, measured by the simple tensile tests. $\sigma_{\max }$ of each alloy increased with increasing $\mathrm{Al}$ content. For $0 \mathrm{Al}, 1 \mathrm{Al}$ and $2 \mathrm{Al}$ specimens, the increasing rate of the stress was approximately $75 \mathrm{MPa}$ per 1 at $\% \mathrm{Al}$. The rate for $3 \mathrm{Al}$ to $6 \mathrm{Al}$ specimens is considerably smaller than that for $0 \mathrm{Al}$ to $2 \mathrm{Al}$. It should be noted here that all the specimens in Fig. 2 yielded twice before the stress reached $\sigma_{\max }$. There are many reports that the $\beta$-type Ti alloys exhibits a stress induced martensitic transformation from parent phase ( $\beta$ : body centered cubic) to martensite phase ( $\alpha^{\prime \prime}$ : orthorhombic) ${ }^{29-35)}$ It has also been reported that the shape memory effect and the superelastic behavior of $\beta$-type $\mathrm{Ti}$ alloys are related to the transformation. ${ }^{6,35-38)}$ Therefore, the first yielding in these specimens were induced by martensitic transformation, thus this

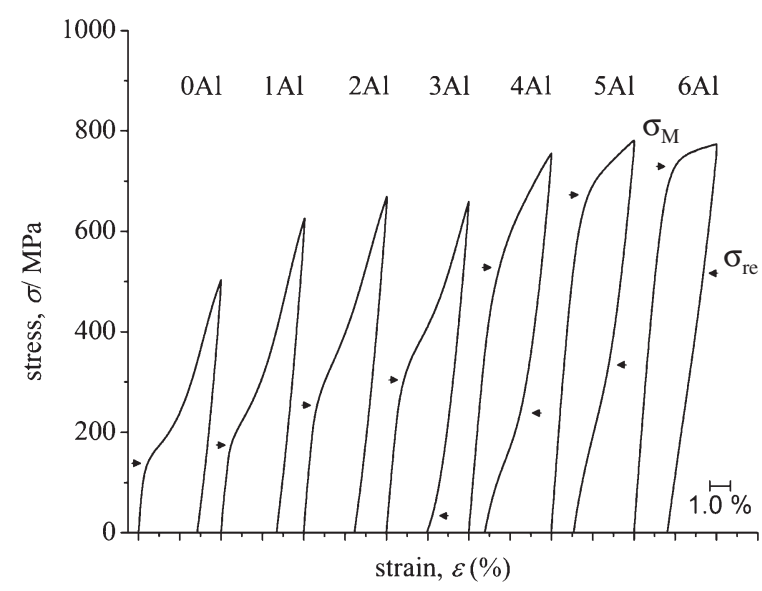

Fig. 3 Stress-strain curves of the $\mathrm{Ti}_{75-x} \mathrm{Nb}_{15} \mathrm{Zr}_{10} \mathrm{Al}_{x}$ specimens solution treated at $973 \mathrm{~K}$ for $600 \mathrm{~s}$. Specimens were subjected to loading-unloading tensile tests where the strain was no more than $4 \%$.

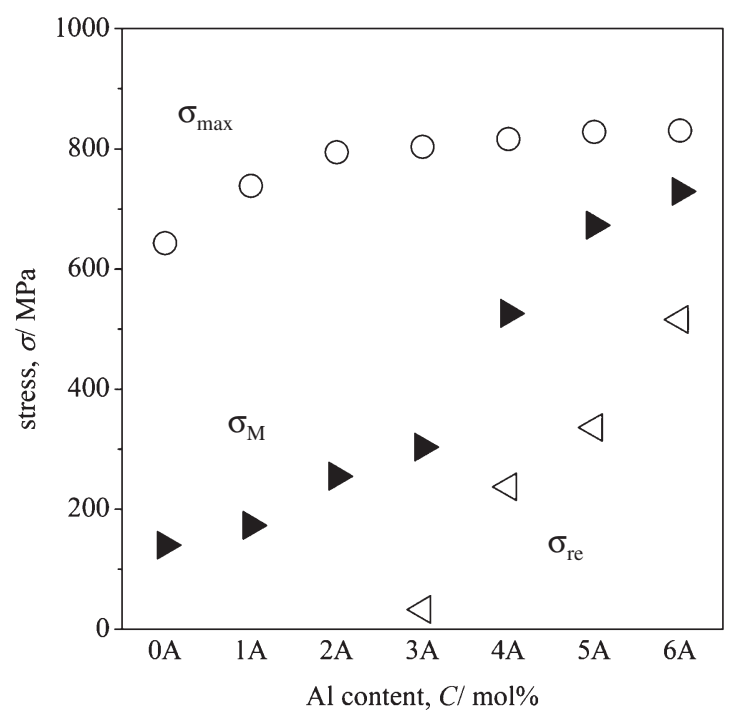

Fig. $4 \sigma_{\max }, \sigma_{\mathrm{M}}, \sigma_{\text {re }}$ of the $\mathrm{Ti}_{75-x} \mathrm{Nb}_{15} \mathrm{Zr}_{10} \mathrm{Al}_{x}$ specimens.

yield stress is denoted as $\sigma_{\mathrm{M}}$ hereafter. The second yield stress, $\sigma_{\mathrm{y}}$, is of the specimen consisting of stress-induced martensite phase.

In order to observe superelastic and shape memory behavior precisely, other solution-treated specimens were also subjected to loading-unloading tensile tests where the strain was no more than $4 \%$. The stress-strain curves for loading-unloading tests were also shown in Fig. 3. $\sigma_{M}$ increased monotonically with increasing $\mathrm{Al}$ content. The specimens with Al content of more than 4 at $\%$ exhibited superelastic behavior. 6Al specimen also exhibited superelastic behavior, but the amount of recovery strain was smaller than specimen $4 \mathrm{Al}$ and $5 \mathrm{Al}$. Both shape memory effect and slight superelastic behavior were exhibited for $3 \mathrm{Al}$ specimen. For those specimens exhibiting superelastic behavior, the reverse transformation stress, $\sigma_{\text {re }}$, also increased with increasing $\mathrm{Al}$ content.

Figure 4 summarizes $\sigma_{\max }, \sigma_{\mathrm{M}}$ and $\sigma_{\text {re }}$, shown in Figs. 2 and 3 . For less than 2 at $\% \mathrm{Al}, \sigma_{\max }$ increased with increasing $\mathrm{Al}$ content. However, $\sigma_{\max }$ was almost stable for the specimens with $\mathrm{Al}$ content of more than 2 at $\%$. On the 


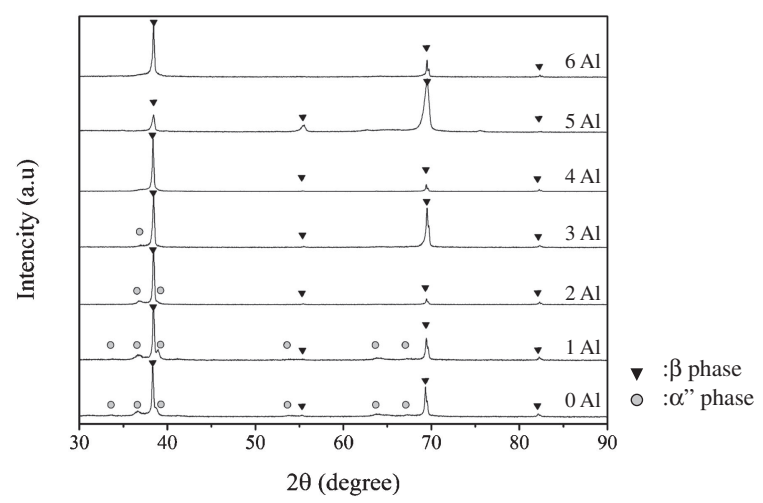

Fig. $5 \mathrm{XRD}$ patterns of the $\mathrm{Ti}_{75-x} \mathrm{Nb}_{15} \mathrm{Zr}_{10} \mathrm{Al}_{x}$ specimens solution-treated at $973 \mathrm{~K}$ for $600 \mathrm{~s}$.

contrary, $\sigma_{\mathrm{M}}$ increased with increasing $\mathrm{Al}$ content without saturation. As a consequence, $\sigma_{\mathrm{M}}$ was comparable to $\sigma_{\max }$ for $6 \mathrm{Al}$ specimen. Thus, it is expected that stress induced martensitic transformation is not observed for the specimen with $\mathrm{Al}$ content more than $7 \mathrm{at} \% \mathrm{Al}$, because the specimen yields before the tensile stress reaches $\sigma_{\mathrm{M}}$. For $0 \mathrm{Al}, 1 \mathrm{Al}$ and $2 \mathrm{Al}$ specimens, $\sigma_{\text {re }}$ could not be measured because reverse martensitic transformation temperature is higher than room temperature. Thus, it is implied that the specimens show shape memory effect when $\mathrm{Al}$ content is no more than 2 at $\%$. For $3 \mathrm{Al}$ specimen, $\sigma_{\text {re }}$ was measured at just above $0 \mathrm{MPa}$ stress. Therefore, the $\mathrm{M}_{\mathrm{s}}$ temperature of $3 \mathrm{Al}$ specimen was estimated to be near room temperature. This is the reason the $3 \mathrm{Al}$ specimen exhibited both shape memory effect and superelastic behavior at room temperature.

Figure 5 shows the XRD patterns of the solution-treated specimens. The diffraction peaks of both $\alpha^{\prime \prime}-\mathrm{Ti}$ and $\beta$-Ti phases were observed in those patterns of $0 \mathrm{Al}, 1 \mathrm{Al}, 2 \mathrm{Al}$ and $3 \mathrm{Al}$ alloys. However, the amount of the $\alpha^{\prime \prime}-\mathrm{Ti}$ phase decreases with increasing $\mathrm{Al}$ content, as the intensity of the diffraction peaks of the $\alpha^{\prime \prime}$-Ti phase becomes low. Specimens with $\mathrm{Al}$ content of more than 4 at $\%$ consisted of almost only of the $\beta$-Ti phase. These results roughly coincide with the loading-unloading tensile tests performed to the solutiontreated specimens as shown in Fig. 3.

In this study, $\sigma_{\mathrm{M}}$ increased with increasing $\mathrm{Al}$ content at room temperature for the solution-treated specimens. This result implies that martensitic transformation start temperature decreases with increasing Al content. The transition temperature from $\alpha$ to $\beta$ for Ti alloy was changed by addition of alloying element. Al has been classified as $\alpha$ stabilizer because it raises the transformation temperature. However, there are some report have shown the influence of $\mathrm{Al}$ addition as a $\beta$ stabilizer. ${ }^{39-41)}$ Our implication agrees with the results that martensitic transformation start temperature decreases with increasing the content of the ternary element added to Ti-Nb-based alloys.

\subsection{Effects of aging corresponding to coating and plating}

The loading-unloading tensile tests were conducted to investigate the effects of aging corresponding to coating and plating on superelastic properties. The specimens with $\mathrm{Al}$ content of 2 to 5 at $\%$ were chosen, because $3 \mathrm{Al}$ and $4 \mathrm{Al}$ specimen exhibited good superelastic property among all the specimens in this study. Some of these specimens were aged at $453 \mathrm{~K}$ for $3.6 \mathrm{ks}$, representing industrial coating condition. Other specimens were aged at $553 \mathrm{~K}$ for $3.6 \mathrm{ks}$, representing industrial plating condition.

The stress-strain curves obtained by the loading-unloading tests are shown in Fig. 6. 2Al specimen exhibited superelastic behavior after aging at $453 \mathrm{~K}$, however, the behavior was not observed for $2 \mathrm{Al}$ specimen aged at $553 \mathrm{~K}$. $5 \mathrm{Al}$ specimen, which exhibited superelastic behavior before aging, lost the behavior after aging. In contrast, $3 \mathrm{Al}$ and $4 \mathrm{Al}$ exhibited superelastic behavior after aging. Among those specimens, $3 \mathrm{Al}$ specimen after aging at $453 \mathrm{~K}$ showed the best superelastic behavior with about $2.5 \%$ of recovery strain.

As far as the specimens were aged in the same condition, the superelastic behavior should monotonically depend on the $\mathrm{Al}$ content. However, only $3 \mathrm{Al}$ and $4 \mathrm{Al}$ specimens exhibited superelastic behavior by aging at 453 and $553 \mathrm{~K}$, while $2 \mathrm{Al}$ and $5 \mathrm{Al}$ specimens did not. In addition, it is noticed that the stress for martensitic transformation $\left(\sigma_{\mathrm{M}}\right)$ of $3 \mathrm{Al}$ and $4 \mathrm{Al}$ specimens decrease with increasing the aging temperature. Superelastic behavior is observed when reverse martensitic transformation temperature is lower than room temperature. Martensitic transformation temperature and reverse martensitic transformation temperature of $\beta$-Ti alloys depends on the composition of the $\beta$-Ti phase and the morphology of the $\omega$ phase often precipitating in the $\beta$-Ti phase. ${ }^{3,13,14,42)}$ It has been also reported that the $\omega$ phase was suppressed by $\mathrm{Al}$ addition. ${ }^{39)}$

TEM bright field images taken along $[110]_{\beta}$ orientation were shown in Fig. 7. Figures 7(a) and 7(b) show the microstructure of the specimen solution-treated at $973 \mathrm{~K}$ for $0.6 \mathrm{ks}$ and aged at $553 \mathrm{~K}$ for $3.6 \mathrm{ks}$, respectively. The corresponding selected area electron diffraction (SAED) patterns are also shown in the insets for each micrograph. Figure 7(c) indicates the key diagram of the diffraction spots of the $\beta$ and $\omega$ phases. In addition to the primary diffraction spots from the $\beta$ matrix, clear extra spots at $1 / 3\{112\}$ positions representing the $\omega$ phase was observed in the SAED pattern of the specimen aged at $553 \mathrm{~K}$. This indicates that the increase of $\sigma_{\mathrm{M}}$ after aging at $553 \mathrm{~K}$ is due to the precipitating the thermal $\omega$ phase. It could be suggested that the precipitation of $\omega$ phase was suppressed more by the addition of $\mathrm{Al}$ for $3 \mathrm{Al}$ and $4 \mathrm{Al}$ specimen compared with $2 \mathrm{Al}$ specimen. In other word, the aging was much more sensitive to $2 \mathrm{Al}$ specimen than to $3 \mathrm{Al}$ and $4 \mathrm{Al}$ specimen. Unfortunately, the microstructure inducing the unique change in superelastic properties by aging $\mathrm{Ti}_{72} \mathrm{Nb}_{15} \mathrm{Zr}_{10} \mathrm{Al}_{3}$ specimen has not been observed yet.

Q. Li et al. has reported that the first yielding stress $\left(\sigma_{\mathrm{M}}\right)$ remain stable at $380 \mathrm{MPa}$ in $\mathrm{TiNb}_{24} \mathrm{Zr}_{2}$ alloy aged at $573 \mathrm{~K}$ for $7.2,10.8$ and $\left.14.4 \mathrm{ks}^{14}\right)$ They described this phenomena is related with the balance of two phenomena. One is suppression of $\beta$ matrix extent and the other is increasing the amount of $\beta$ stabilizing elements. Both phenomena were caused by the aged $\omega$ phase precipitation. H. Y. Kim et al. has reported that dispersed $\omega$ particle mechanically suppress the martensitic transformation. ${ }^{11)} \mathrm{J}$. song et al. has reported that $\mathrm{Ti}-9.8 \mathrm{Mo}-3.9 \mathrm{Nb}-2 \mathrm{~V}-3.1 \mathrm{Al}$ (mass\%) alloy lost a superelastic behavior when the alloy was aged at 473-523 

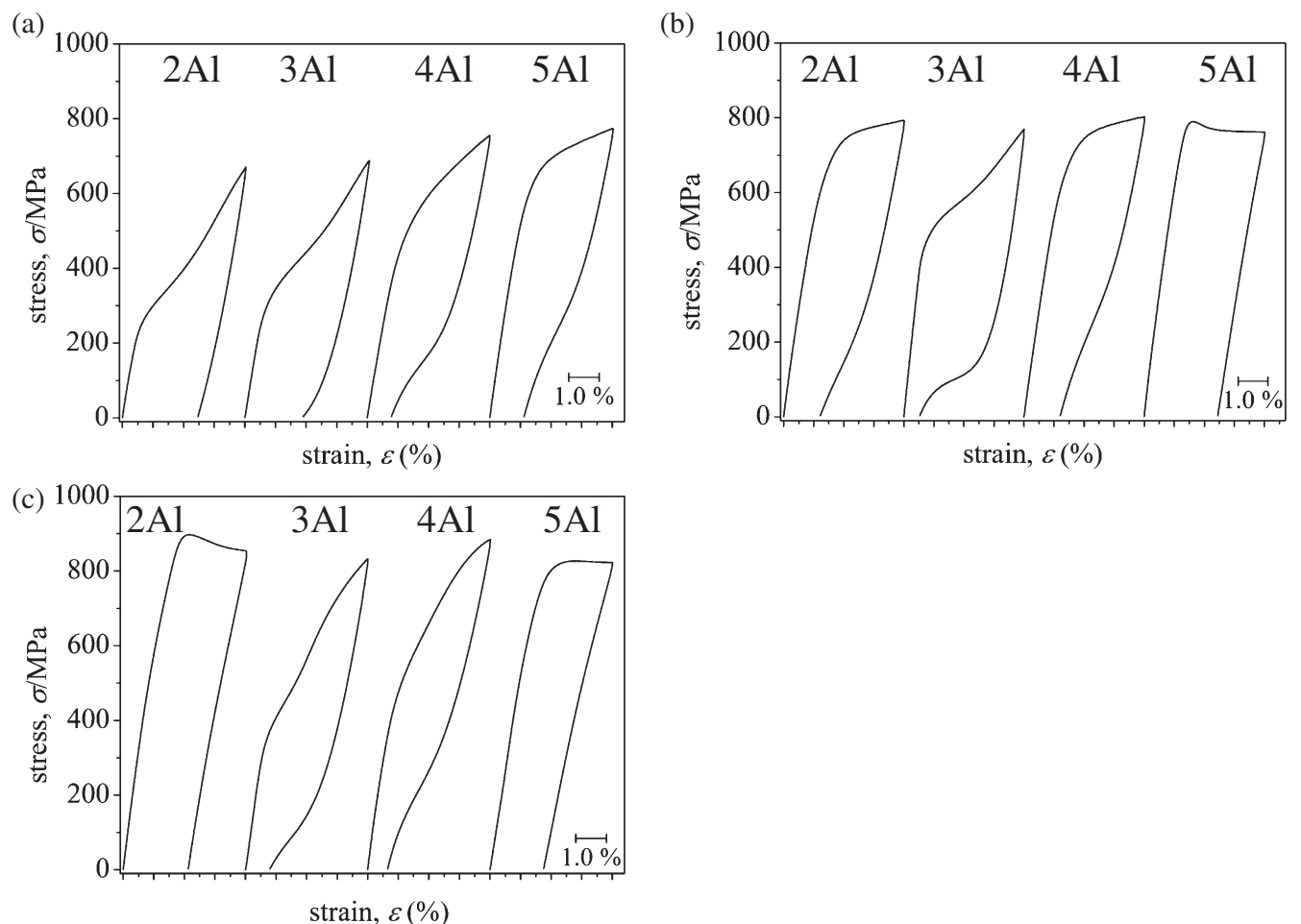

Fig. 6 Stress-strain curves of (a) solution-treated specimens, (b) specimens aged at $453 \mathrm{~K}$ for $3.6 \mathrm{ks}$ and (c) specimens aged at $553 \mathrm{~K}$ for $3.6 \mathrm{ks}$.

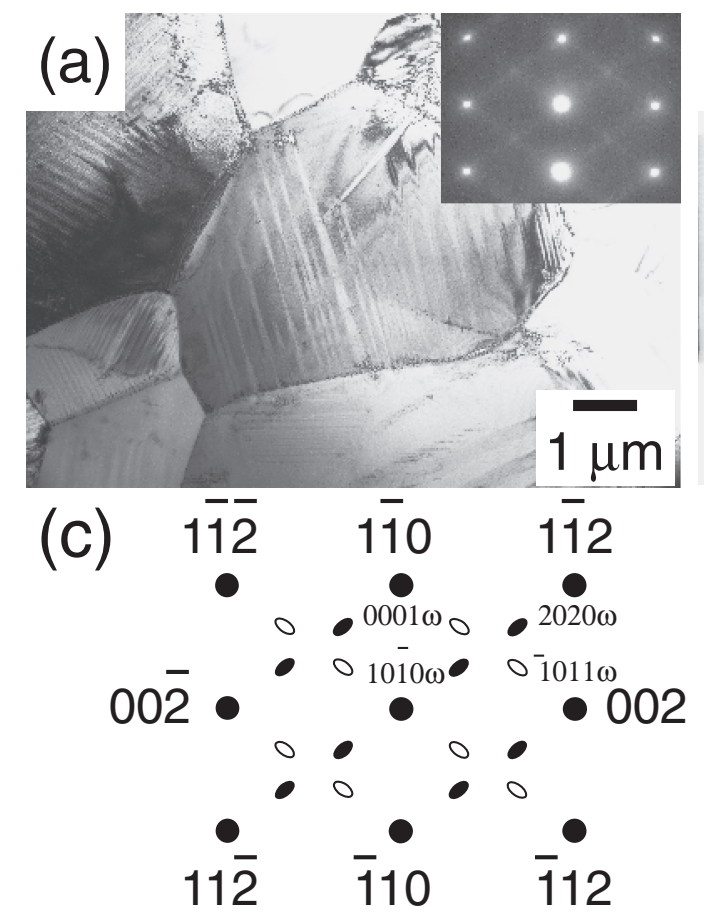

(b)

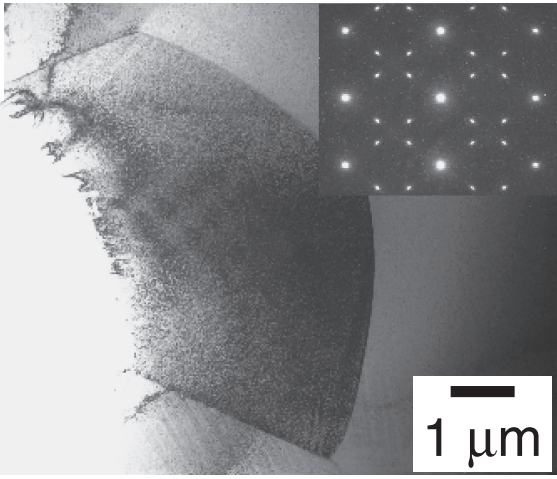

Fig. 7 Bright field TEM micrographs and the corresponding SAED patterns of (a) the solution-treated $\mathrm{Ti}_{72} \mathrm{Nb}_{15} \mathrm{Zr}_{10} \mathrm{Al}_{3}$ specimen and (b) the specimen aged at $553 \mathrm{~K}$ for $3.6 \mathrm{ks}$. (c) Key diagram of the diffraction spot of the $\beta$ and $\omega$ phases.

and $773-823 \mathrm{~K}$. Even though the alloy demonstrated the superelastic behavior after aging at $673,873,973 \mathrm{~K} .{ }^{43)}$ They estimated that the phenomena related to a precipitating and coarsening of $\alpha$ and $\omega$ phase. However, the effects of aging temperature of these specimens are still not clear completely yet. In order to detailed investigation, long period aged specimens are preparing. Thus, it is expected to precipitate the microstructure clearly which is considered to cause this strange phenomena. This non-monotonical change of superelastic behavior as a function of $\mathrm{Al}$ content and aging temperature is still under investigation and will be discussed elsewhere. 


\section{Conclusions}

$\mathrm{Ti}-\mathrm{Nb}-\mathrm{Zr}-\mathrm{Al}$ alloys which exhibit superelastic behavior after industrial coating and plating were developed, and their mechanical properties were investigated.

$3 \mathrm{Al}\left(\mathrm{Ti}_{72} \mathrm{Nb}_{15} \mathrm{Zr}_{10} \mathrm{Al}_{3}\right)$ and $4 \mathrm{Al}\left(\mathrm{Ti}_{71} \mathrm{Nb}_{15} \mathrm{Zr}_{10} \mathrm{Al}_{4}\right)$ specimens exhibited superelastic behavior even after aging at industrial coating and plating temperature, 453 and $553 \mathrm{~K}$, while other specimens did not. The largest recovery strain due to superelastic behavior was about $2.5 \%$ and was observed for $3 \mathrm{Al}$ specimen.

The superelastic behavior of the $\mathrm{Ti}-\mathrm{Nb}-\mathrm{Zr}-\mathrm{Al}$ alloys after aging did not change monotonically as a function of $\mathrm{Al}$ content. Superelastic behavior could not be observed after aging at 453 and $553 \mathrm{~K}$ for $2 \mathrm{Al}$ and $5 \mathrm{Al}$ specimens. Only $3 \mathrm{Al}$ and $4 \mathrm{Al}$ specimens exhibited superelastic behavior after aging in the same condition.

\section{REFERENCES}

1) D. Kuroda, M. Niinomi, M. Morinaga, Y. Kato and T. Yashiro: Mater Sci. Eng. A 243 (1998) 244-249.

2) A. Biesiekierski, J. Wang, M. A. H. Gepreel and C. Wen: Acta Biomater. 8 (2012) 1661-1669.

3) E. Takahashi, T. Sakurai, S. Watanabe, N. Masahashi and S. Hanada: Mater. Trans. 43 (2002) 2978-2983.

4) H. Y. Kim, Y. Ohmatsu, J. I. Kim, H. Hosoda and S. Miyazaki: Mater. Trans. 45 (2004) 1090-1095.

5) T. Maeshima and M. Nishida: Mater. Trans. 45 (2004) 1096-1100.

6) J. I. Kim, H. Y. Kim, H. Hosoda and S. Miyazaki: Mater. Trans. 46 (2005) 852-857.

7) J. I. Kim, H. Y. Kim, T. Inamura, H. Hosoda and S. Miyazaki: Mater. Sci. Eng. A 403 (2005) 334-339.

8) H. Y. Kim, H. Satoru, J. I. Kim, H. Hosoda and S. Miyazaki: Mater. Trans. 45 (2004) 2443-2448.

9) T. Zhou, M. Aindow, S. P. Alpay, M. J. Blackburn and M. H. Wu: Scr. Mater. 50 (2004) 343-348.

10) D. H. Ping, Y. Mitarai and F. X. Yin: Scr. Mater. 52 (2005) 1287-1291.

11) H. Y. Kim, Y. Ikehara, J. I. Kim, H. Hosoda and S. Miyazaki: Acta Mater. 54 (2006) 2419-2429.

12) H. Hosoda, Y. Kinoshita, Y. Fukui, T. Inamura, K. Wakashima, H. Y. Kim and S. Miyazaki: Mater. Sci. Eng. A 438-440 (2006) 870-874.

13) Y. Al-Zain, H. Y. Kim, H. Hosoda, T. H. Nam and S. Miyazaki: Acta Mater. 58 (2010) 4212-4223.

14) Q. Li, M. Niinomi, M. Nakai, Z. Cui, S. Zhu and X. Yang: Metall. Mater. Trans. A 42 (2011) 2843-2849.

15) H. Y. Kim, J. I. Kim, T. Inamura, H. Hosoda and S. Miyazaki: Mater.
Sci. Eng. A 438-440 (2006) 839-843.

16) H. Hosoda, M. Taniguchi, T. Inamura, H. Kanetaka and S. Miyazaki: Mater. Sci. Forum 654-656 (2010) 2150-2153.

17) J. I. Kim, H. Y. Kim, T. Inamura, H. Hosoda and S. Miyazaki: Mater. Trans. 47 (2006) 505-512.

18) H. Y. Kim, S. Hashimoto, J. I. Kim, T. Inamura, H. Hosoda and S. Miyazaki: Mater. Sci. Eng. A 417 (2006) 120-128.

19) Y. L. Hao, S. J. Li, S. Y. Sun and R. Yang: Mater. Sci. Eng. A 441 (2006) 112-118.

20) J. C. Williams, B. S. Hickman and D. H. Leslie: Metall. Mater. Trans. B 2 (1971) 477-484

21) T. Inamura, Y. Fukui, H. Hosoda, K. Wakashima and S. Miyazaki: Mater. Sci. Eng. C 25 (2005) 426-432.

22) S. Ishiyama, S. Hanada and O. Izumi: ISIJ Int. 31 (1991) 807-813.

23) Y. Horiuchi, T. Inamura, H. Y. Kim, S. Miyazaki, K. Wakashima and H. Hosoda: Mater. Trans. 47 (2006) 1209-1213.

24) H. Y. Kim, N. Oshika, J. I. Kim, T. Inamura, H. Hosoda and S. Miyazaki: Mater. Trans. 48 (2007) 400-406.

25) Y. Fukui, T. Inamura, H. Hosoda, K. Wakashima and S. Miyazaki: Mater. Trans. 45 (2004) 1077-1082.

26) N. Sakaguch, M. Niinomi and T. Akahori: Mater. Trans. 45 (2004) $1113-1119$.

27) M. Nakai, M. Niinomi and T. Oneda: Metall. Mater. Trans. A 43 (2012) 294-302.

28) M. Niinomi: Biomater. 24 (2003) 2673-2683.

29) C. Baker: Metal Sci. J. 5 (1971) 92-100.

30) R. Davis, H. M. Flower and D. R. F. West: J. Mater. Sci. 14 (1979) 712-722.

31) D. L. Moffat and U. R. Kattner: Metall. Mater. Trans. A 19 (1988) 2389-2397.

32) T. Ahmed and H. J. Rack: J. Mater. Sci. 31 (1996) 4267-4276.

33) A. V. Dobromyslov and V. A. Elkin: Scr. Mater. 44 (2001) 905-910.

34) N. B. D'yakonova, I. V. Lyasotskii and Y. I. Rodionov: Russ. Metall. 2007 (2007) 51-58.

35) L. C. Zhang, T. Zhou, M. Aindow, S. P. Alpay, M. J. Blackburn and M. H. Wu: J. Mater. Sci. 40 (2005) 2833-2836.

36) T. Grosdidier and M. J. Philippe: Mater. Sci. Eng. A 291 (2000) 218223.

37) A. R. G. Brown, D. Clark, J. Eastabrook and K. S. Jepson: Nature 201 (1964) 914-915.

38) M. Tahara, H. Y. Kim, H. Hosoda and S. Miyazaki: Acta Mater. 57 (2009) 2461-2469.

39) P. J. S. Buenconsejo, H. Y. Kim and S. Miyazaki: Acta Mater. 57 (2009) 2509-2515.

40) H. Ohyama and T. Nishimura: ISIJ Int. 35 (1995) 927-936.

41) L. A. Matlakhova, A. N. Matlakhov, S. N. Monteiro, S. G. Fedotov and B. A. Goncharenko: Mater. Sci. Eng. A 393 (2005) 320-326.

42) S. Neelakantan, P. E. J. R. Castillo and S. Zwaag: Scr. Mater. 60 (2009) 611-614.

43) J. Song, X. Zhang, X. Sum, H. Jiang, Z. Fan, C. Xie and M. H. Wu: J. Mater. Eng. Perform. 21 (2012) 366-372. 